DOI: $10.19195 / 2084-5065.39 .4$

\title{
Dyrektywa pozytywnej prewencji ogólnej - wybrane problemy. Uwagi na tle kodeksu karnego
}

\author{
AgNIESZKA KANIA \\ Katedra Prawa Karnego i Postępowania Karnego, \\ Wydział Prawa i Administracji Uniwersytetu Zielonogórskiego
}

\section{Wprowadzenie w problematykę}

Wprowadzenie do przepisów obowiązującego kodeksu karnego zasady humanitaryzmu - art. 3 k.k. ${ }^{1}$ — oraz dyrektywy stopnia winy — art. $53 \S 1$ k.k., in principio korespondowało z jego politycznokryminalnymi oraz aksjologicznymi założeniami ${ }^{2}$. Z powyższym kierunkiem zmian korelowała także dyrektywalna treść prewencji ogólnej („potrzeby w zakresie kształtowania świadomości prawnej społeczeństwa" - art. 53 $\S 1$ k.k. in fine), która — w założeniu kodyfikatorów — nie pozwalała na traktowanie kary kryminalnej jako narzędzia ostrej, a wręcz niekiedy

${ }^{1}$ Ustawa Kodeks karny z dn. 6 czerwca 1997 r., tj. z dn. 5 lipca 2016 r, Dz.U. poz. 1197 (cyt. dalej jako kodeks karny — k.k.).

2 T. Kaczmarek, Nowy polski kodeks karny i jego aksjologiczne oraz kryminalnopolityczne założenia, „Nowa Kodyfikacja Prawa Karnego” 1998, nr 3, s. 9 n.; idem, Kryminalnopolityczne założenia nowego kodeksu karnego, „Nowa Kodyfikacja Prawa Karnego" 1997, nr 1, s. 13 n. 
przesadnej represji ${ }^{3}$. Zgodnie $\mathrm{z}$ intencją twórców obowiązującej kodyfikacji karnej, rola dyrektywy ogólnoprewencyjnej sprowadzała się do wyznaczenia dolnej granicy wymierzonej sprawcy kary. Z „Uzasadnienia do projektu kodeksu karnego” wynikało bowiem wprost, że: „Dolną granicę konkretnej kary wyznaczają w zasadzie: ,[...] potrzeby stabilizacji (porządku prawnego, utożsamianego z pozytywną prewencją ogólną - podkr. moje), górną natomiast wyznacza (limituje) zasada winy. W tych granicach sąd może wymierzyć karę według potrzeb prewencji indywidualnej" 4 . Powyższe stanowisko nie rozstrzygało przy tym, czy wspomniane „graniczne” dyrektywy współwyznaczają rodzaj i rozmiar kary, czy też ich znaczenie sprowadza się tylko do funkcji limitującej wymiar kary ${ }^{5}$.

3 Warto w tym miejscu wspomnieć, że w okresie obowiązywania poprzedniego kodeksu karnego doszło do swoistego wypaczenia istoty dyrektywy ogólnoprewencyjnej. Zob. w szczególności prezentowane wówczas poglądy orzecznictwa: Wyrok Sądu Najwyższego z dnia 7 listopada 1969 r., II KR 128/69, „Nowe Prawo” 1970, nr 4, s. 629-631, Uchwała Sądu Najwyższego z dnia 21 grudnia 1972 r., VI KZP 64/72, OSNKW 1973, nr 2-3, poz. 18, Wyrok Sądu Najwyższego z dnia 8 maja 1974 r., V KRN 33/74, OSNKW 1974, nr 9, poz. 166, Uchwała Sądu Najwyższego z dnia 26 września 1975 r., VI KZP 14/75, OSNKW 1975, nr 10-11, poz. 134, Uchwała Sądu Najwyższego z dnia 28 kwietnia 1978 r., VII KZP 15/76, OSNKW 1978, nr 4-5, poz. 41; K. Buchała, Wytyczne wymiaru sprawiedliwości i praktyki sadowej w spawach o przestępstwa drogowe, ,Nowe Prawo" 1975, nr 10-11, s. 1288-1289 oraz T. Kaczmarek, W sprawie nadmiernej represyjności polityki karnej, „Państwo i Prawo” 1981, nr 5, s. 101-105.

4 Nowe kodeksy karne z uzasadnieniem, Warszawa 1997, s. 153; Wyrok Sądu Apelacyjnego Krakowie z dnia 24 października 2002 r., II AKa 258/02, „Krakowskie Zeszyty Sądowe” 2002, nr 10, poz. 52, w którym stwierdzono, że: „Wymiar kary kształtowany jest tak, iż górną granicę limituje stopień winy, dolną zaś wyznaczają potrzeby prewencji ogólnej".

5 W ocenie M. Dąbrowskiej-Kardas, spór ten może wydawać się pozorny. Z zaprezentowanego stanowiska autorki wynikało bowiem, że: ,[...] nawet wówczas, gdyby przyjąć pogląd, że wina tylko limituje wymiar kary, to i tak oznacza to przecież, że w taki właśnie sposób - współwyznacza go. A zatem okoliczności wpływające na stopień winy są brane pod uwagę przy wymiarze kary, oczywiście przede wszystkim przez pryzmat jej funkcji limitującej, jednak przecież nie da się miejsca tej funkcji limitującej oznaczyć przy wymiarze konkretnej kary, bez odniesienia okoliczności wpływających na stopień winy do pozostałych przesłanek wymiaru kary. Stąd trudno chyba bronić poglądu, że stopień winy to pewna przesłanka, która przy wymiarze kary jest całkowicie oderwana od pozostałych i abstrakcyjnie wyznacza pewną górną granicę tego wymiaru". 
Koncentrując uwagę na treści dyrektywy ogólnoprewencyjnej ${ }^{6}$, należy przy tym zaznaczyć, że we wspomnianym Uzasadnieniu... wyraźnie stwierdzono, iż nowy kodeks karny odrzuca cele polegające na odstraszaniu $^{7}$ społeczeństwa ${ }^{8}$. W przekonaniu autorów obowiązującego kodeksu istotą oddziaływania pozytywnoprewencyjnego pozostawało bowiem dążenie do uzyskania stabilizacji porządku prawnego ${ }^{9}$. Stąd też uznano, że kara realizująca wspomniany cel ogólnoprewencyjny nie powinna być: „,...] niższa od stopnia tolerancji, poniżej którego powstaje przekonanie, że chronione normą wartości nie znajdują w rzeczywistości ochrony, ze względu na zbyt liberalne traktowanie przestępców naruszających dobra prawne" 10 .

Ponadto, za równie doniosły czynnik umożliwiający kształtowanie świadomości prawnej społeczeństwa twórcy kodeksu karnego z 1997 r. uznali: wysoki stopień wykrywalności przestępstw, nieuchronność pono-

M. Dąbrowska-Kardas, Analiza dyrektywalna przepisów części ogólnej kodeksu karnego, Warszawa 2012, s. 266-267, s. 270 i lit. tam podana.

6 Wyrok Sądu Apelacyjnego w Szczecinie z dnia 6 lutego 2014 r., II AKa 1/14, LEX nr 1441560.

7 J. Felczak, Polski system penitencjarny. Racjonalizacja kosztów, Warszawa 2014, s. 159.

8 Nowe kodeksy karne z..., s. 153. W judykaturze zwrócono jednak uwagę, że: „Istota prewencyjnego oddziaływania kary polega na wpływaniu - także poprzez jej niezbędną, to jest konieczną surowość - na kształtowanie postaw moralnych, organizujących społeczeństwa, wiarę w nie i ufność w celowość przestrzegania norm systemy te tworzących [...]. Wyrok Sądu Apelacyjnego w Gdańsku z dnia 9 maja 2002 r., II AKa 526/01, „Krakowskie Zeszyty Sądowe” 2002, nr 10, poz. 69; Wyrok Sądu Apelacyjnego w Krakowie z dnia 1 lutego 2001 r., II AKa 3/01, „Krakowskie Zeszyty Sądowe” 2001, nr 2, poz. 22, w którym z kolei wyraźnie stwierdzono, że: „Osiąganie celów ogólnoprewencyjnych poprzez wykorzystywanie społecznego oddziaływania kary nie powinno odbywać się kosztem sprawiedliwości. Wymierzanie kar zbyt surowych nie tylko nie umacnia poszanowania prawa, ufności w celowość przestrzegania norm prawnych organizujących społeczeństwo ani zaufania do organów prawo realizujących, ale nawet przeciwnie - może wywoływać mimowolne współczucie społeczeństwa dla przestępcy zbyt surowo ukaranego"; Wyrok Sądu Apelacyjnego we Wrocławiu z dnia 13 marca 2013 r., II AKa 47/03, „Krakowskie Zeszyty Sądowe” 2003, nr 12, poz. 30; Wyrok Sądu Apelacyjnego we Wrocławiu z dn. 6 maja 2005 r., II AKa 112/05, LEX nr 171983.

9 Nowe kodeksy karne z uzasadnieniem, Warszawa 1997, s. 153.

10 A. Zoll, Zalożenia polityki karnej w projekcie kodeksu karnego, „Państwo i Prawo" 1994, nr 5, s. 7. 
szenia odpowiedzialności ${ }^{11}$, a także stosowanie kar (czy też innych środków reakcji prawnokarnej), które w ocenie społecznej zostałyby uznane jako przykład sprawiedliwej reakcji ${ }^{12}$.

Nie zaprzeczając doniosłości wspomnianych czynników, wydaje się jednak, że gwarancję wykrywalności oraz nieuchronności ponoszenia odpowiedzialności powinny zapewniać organy, do których kompetencji należy ściganie przestępstw ${ }^{13}$. Stąd też wątpliwe pozostawałoby bazowanie na tych wartościach przez sąd orzekający w momencie, w którym odwoływałby się do treści dyrektywy ogólnoprewencyjnej. Jednocześnie nie sposób w tym miejscu pominąć, że wyróżnioną nieuchronność trudno byłoby zresztą uwzględnić przed wymierzeniem kary, skoro dopiero zastosowanie konkretnej reakcji penalnej czyni ją de facto nieuchronną ${ }^{14}$. W konwencję zgłoszonych zastrzeżeń wpisuje się także kontrowersyjne w istocie powiązanie sensu dyrektywy prewencji ogólnej z przekazywaniem społeczeństwu informacji: ,[...] o normach sankcjonowanych oraz karach orzekanych za ich złamanie, co spełnia - jak wskazano w cytowanym Uzasadnieniu — też funkcję potwierdzania obowiązywania tych norm"15. Jak można przypuszczać, urzeczywistnienie tego aspektu oddziaływania ogólnoprewencyjnego wymagałoby niewątpliwie zaangażowania środków informacji masowej, za pośrednictwem których wiadomości o normach, a precyzując - o toczących się sprawach oraz wydanych wyrokach - docierałyby na szeroką skalę. W konsekwencji wypadłoby więc podkreślić, że w optyce medialnej, wbrew powszechnej, utartej praktyce, powinny tym samym znaleźć się nie tylko głośne, szczególnie bulwersujące sprawy, ale przede wszystkim te ,mało barw-

11 C. Beccaria, O przestępstwach i karach, Warszawa 1959, s. 138. W tym miejscu warto jednocześnie wspomnieć o słowach L. Gardockiego, w których autor napominał, że: „tezy o przewadze nieuchronności kary nad surowością nie należy traktować w sposób uproszczony. Jest bowiem jasne, że nawet zbliżona do stuprocentowej nieuchronność nie powstrzyma przestępcy, jeżeli grożąca mu kara będzie bardzo łagodna. Ale nie znaczy to - jak podkreślił autor — że przez zaostrzenie prawa karnego da się osiągnąć znaczące rezultaty w zwalczaniu przestępczości”. L. Gardocki, Naprawdę jesteśmy trzeciq władza, Warszawa 2008, s. 126.

12 Projekt kodeksu karnego, Warszawa 1995, s. 39.

13 J. Felczak, op. cit., s. 160 i lit. tam podana.

14 J. Kulesza, Negatywna prewencja generalna, „Państwo i Prawo” 2011, nr 1, s. 42.

15 Nowe kodeksy karne..., s. 153. 
ne", których zobrazowanie przekonywałoby opinię publiczną o czujności oraz gotowości organów ścigania do walki z przestępczością ${ }^{16}$.

\section{Kontrowersje dotyczące dyrektywalnego statusu prewencji ogólnej}

„Kształtowanie świadomości prawnej społeczeństwa”, jako treść dyrektywy ogólnoprewencyjnej (art. $53 \S 1$ k.k. in fine), wzbudza szereg kontrowersji nie tylko na płaszczyźnie teorii, lecz także na gruncie praktyki stosowania prawa. Zasygnalizowane w ten sposób wattpliwości wynikają już z samego ujęcia redakcyjnego wspomnianej dyrektywy. W pierwszej kolejności wypada zaznaczyć, że wspomniane powyżej kodeksowe nawiązanie do ,potrzeb w zakresie kształtowania świadomości prawnej społeczeństwa” akcentuje w swej treści przede wszystkim „,socjalizowanie” oraz „społeczne integrowanie”, które stanowią przykład zadań eksponowanych nie tyle na gruncie polityki kryminalnej, lecz na płaszczyźnie edukacji moralnej czy też edukacji szkolnej w ramach form popularyzacji prawa ${ }^{17}$. Przy takim ujęciu system prawnokarny musiałby zatem wypracować konstruktywny model wywierania wpływu na przekonania społeczne, wykazujący pewne podobieństwo do metod wdrażanych w tym zakresie m.in. przez środowiska szkolne czy rodzinne. W tym miejscu pojawia się jednak pytanie — czy wspomniana redakcja dyrektywy ogólnoprewencyjnej nie formułuje w istocie w „nadambitny” sposób oczekiwań stawianych przed karą kryminalną?

W sceptycznej ocenie aktualnej redakcji dyrektywy prewencji ogólnej utwierdza także odwołanie się przez ustawodawcę do samego pojęcia „świadomości prawnej” ${ }^{18}$. Powyższe określenie odzwierciedla

16 M. Szerer, Karanie a humanizm, Warszawa 1964, s. 147.

${ }^{17}$ L. Wilk, Kwestia prewencji ogólnej na tle kodeksu karnego z 1997 r., „Państwo i Prawo" 2000, nr 2, s. 54; por także A. Marek, Komentarz do kodeksu karnego. Część ogólna, Warszawa 1999, s. 157. Na temat kontrowersji dotyczących dyrektywalnego statusu prewencji ogólnej zob. A. Kania, Prewencja ogólna jako dyrektywa sqdowego wymiaru kary. Rozważania na tle kodeksu karnego, Zielona Góra 2016, s. 251 n.

18 Warto w tym miejscu nadmienić, że wyrażenie „świadomość prawna” nawiązuje silnie do pojęć eksponowanych w poprzednim ustroju państwowym. A. Tybur, Rola Prokuratury w ksztaltowaniu świadomości prawnej spoleczeństwa, „Problemy Prawo- 
niewątpliwe element kultury prawnej ${ }^{19}$, co jednocześnie nie eliminuje innej, zdecydowanie bardziej złożonej kwestii, jaka wiąże się z jego zdefiniowaniem w literaturze socjologicznej. Pojawiające się w tym zakresie różnice definicyjne wynikają przede wszystkim z odmiennych stanowisk, w których opowiedziano się za mniej bądź bardziej rozbudowanym ujęciem komentowanej ,świadomości prawnej”. Wobec zaprezentowanej w tym zakresie polaryzacji poglądów ${ }^{20}$ nie sposób odmówić racji A. Podgóreckiemu, że: „Niekiedy pewne terminy teoretyczne zdobywają sobie popularność naukową mimo że nie jest jasna ani ich geneza, ani sens, w jakim są używane. Tak właśnie jest — jak przekonywał autor - z pojęciem: świadomość prawna. Niemniej w tych przypadkach, w których terminy teoretyczne są już powszechnie przyjęte, nie warto ich zmieniać, choćby dlatego, by nie mnożyć nieporozumień terminologicznych" 21 .

Uzasadnione watpliwości nasuwa także dalsze brzmienie omawianej dyrektywy, w którym ustawodawca utożsamił adresata oddziaływania ogólnoprewencyjnego z bezimiennym „ogółem” społeczeństwa. W rzeczywistości bowiem odbiorcą informacji o wyrokach w sprawach karnych okazuje się zawężony krag osób ograniczający się — poza stricte medialnymi przypadkami - do najbliższego otoczenia pokrzywdzonego oraz sprawcy $^{22}$. Ogólnoprewencyjny zasięg wymierzonej kary pozostaje w konsekwencji — posługując się terminologią arytmetyczną - w stosunku wprost proporcjonalnym do długości promienia koła, w jakiej roz-

rządności” 1975, nr 9, s. 7-8; J. Wojciechowska, Kształtowanie świadomości prawnej społeczeństwa (Sympozjum w Warszawie), „Państwo i Prawo” 1974, nr 2, s. 147; M. Borucka-Arctowa, Świadomość prawna a planowe zmiany społeczne, Wrocław 1981, s. 5 n.

19 A. Gryniuk, Kultura prawna a świadomość prawna, „Państwo i Prawo” 2002, nr 1, s. 31 .

${ }^{20}$ Prezentowane poniżej stanowiska przytaczam za: A. Pieniążek, M. Stefaniuk, Socjologia prawa. Zarys wykładu, Kraków 2001, s. 175-176.

21 A. Podgórecki, Świadomość prawna - w świetle badań empirycznych, „Państwo i Prawo" 1971, nr 12, s. 943.

${ }^{22}$ K. Skowroński, Ogólne dyrektywy sq̨owego wymiaru kary w kodeksie karnym z 1997 r., „Palestra” 2003, nr 8, s. 84. Trafnie ocenił więc K. Buchała, że określenie „prewencja ogólna” okazuje się do „pewnego stopnia mylącym sformułowaniem”. K. Buchała, Dyrektywy sqdowego wymiaru kary, Warszawa 1964, s. 79-80, 90. 
chodzi się o niej wiadomość ${ }^{23}$. Pewną naiwnością pozostaje więc przekonanie, że możliwość pozytywnego wpływu orzeczonej kary rozciąga się na kształtowanie postaw całego społeczeństwa ${ }^{24}$. Reasumując, wypada zatem stwierdzić, że w świetle obowiązującej redakcji dyrektywy ogólnoprewencyjnej podstawową rolę przy wyznaczeniu kręgu adresatów powinno odgrywa prawidłowe wyznaczenie terytorialnego zasięgu oddziaływania wydanego przez sąd orzeczenia. Podjęcie tego rodzaju przedsięwzięcia wymagałoby z kolei gruntownego rozpoznania właściwości oraz poglądów określonego środowiska społecznego, które nie tylko musiałoby zapoznać się z treścią konkretnej decyzji sądowej, lecz także zostałoby zobligowane do wyrażenia swojej opinii na jego temat ${ }^{25}$.

Do wyrażenia dalszych, równie krytycznych uwag, skłania ponadto odczasownikowe określenie zawarte w niniejszym przepisie, w którym ustawodawca odwołał się do - z istoty rozłożonego temporalnie - procesu „kształtowania”. W judykaturze wyraźnie bowiem podniesiono, że: „Istota prewencyjnego oddziaływania kar polega [...] na wpływaniu [...] na kształtowanie się postaw moralnych, organizujących społeczeństwa, wiarę $\mathrm{w}$ nie i ufność $\mathrm{w}$ celowość przestrzegania norm systemy te tworzący$\mathrm{ch}^{\text {"26 }}$. Sens niniejszego określenia sugeruje więc - już prima facie - konieczność podejmowania długofalowych przedsięwzięć „edukacyjnych”, których pożąanym skutkiem byłoby przekonanie społeczeństwa o wartości, jaką niesie za sobą przestrzeganie norm prawnych. Osiagnnięcie tego rezultatu, przybierającego finalnie postać swoistego „nawyku” respektowania prawa obowiązującego, wymagałoby zaś systematycznego podejmowania pewnej sekwencji działań kształtujących postawy pronormatywne. Trafnie więc oceniono w piśmiennictwie, że powyższe sformułowanie dyrektywy ogólnoprewencyjnej nie będzie posiadało - z perspektywy sądowego wymiaru kary - samodzielnego waloru praktycznego. Na

23 M. Szerer, s. 164-165.

24 M. Królikowski, S. Żółtek, [w:] M. Błaszczyk et al., Kodeks karny. Część ogólna. Komentarz do art. 32-116, t. 2, red. M. Królikowski, R. Zawłocki, Warszawa 2010, s. 279.

${ }^{25}$ Nie sposób w tym miejscu pominąć, że tego rodzaju ustalanie treści dyrektywy ogólnoprewencyjnej nie pozostawałoby wolne od zarzutu bazowania na w istocie „mglistym" materiale badawczym. Zob. także dalsze uwagi.

${ }^{26}$ Wyrok Sądu Apelacyjnego w Krakowie z dnia 14 lutego 1991 r., II AKr 3/91, „Krakowskie Zeszyty Sądowe” 1991, nr 3, poz. 8. 
jego podstawie trudno byłoby zresztą wyodrębnić bezpośredni, socjologiczny efekt karania ${ }^{27}$. Wobec powyższej uwagi, należałoby tym samym stwierdzić, że w świetle aktualnej redakcji art. $53 \S 1$ k.k., pozytywnoprewencyjny sens kary nawiązuje w istocie do pewnej kategorii psychologicznej, czyli czegoś, do czego się dąży, co się wyznacza do spełnienia i co w ostateczności pozostaje jedynie w sferze pragnieńn ${ }^{28}$. Ustawowy cel pozytywnoprewencyjny odzwierciedla bowiem jedynie zamierzone oddziaływanie, którego przyszłościowych efektów, polegających na „wprawieniu" społeczeństwa w zaufanie do obowiązujących norm prawnych ${ }^{29}$, oczekuje się w związku ze stosowanymi sankcjami karnymi ${ }^{30}$. Innymi słowy, wspomniane oddziaływanie pozytywnoprewencyjne posiada de facto charakter stricte następczy, uzależniony od faktycznie potwierdzonego wpływu orzeczonych przez sądy środków reakcji penalnej na proces kształtowania świadomości prawnej społeczeństwa.

W istotę wyrażonych uwag wpisują się ponadto te poglądy, w których przekonywano, że określenie prewencji ogólnej przez pryzmat „kształtowania” społecznych postaw wobec oceny zjawisk kryminogennych pozostaje w sprzeczności z art. 2 Konstytucji RP. W przedstawionej argumentacji zwrócono bowiem uwagę, że wyeksponowany w art. 53 $\S 1$ k.k. postulat edukowania społeczeństwa przesuwa tym samym na dalszy plan potrzebę uwzględnienia poglądów opinii społecznej w zakresie wymierzanych $\mathrm{kar}^{31}$. Wyrażone tutaj stanowisko wymaga jednakże pewnego uściślenia.

27 L. Wilk, op. cit., s. 54

28 Ibidem, s. 53.

29 W. Hassemer, Einführung in die Grundlagen des Strafrechts, München 1990; R. Schmidt, Strafrecht. Allgemeiner Teil. Grundlagen der Strafbarkeit. Methodik der Fallbearbeitung, Hamburg 2012, s. 5; P. Bringewat, Grundbegriffe des Strafrechts. Grundlagen - Allgemeine Verbrechenslehre - Aufbauschemata, Baden-Baden 2008, s. 38; W. Hassemer, Einige Bemerkungen über ,positive Generalprävention”, [w:] Problemy odpowiedzialności karnej. Księga pamiatkowa ku czci Profesora Kazimierza Buchały, red. Z. Ćwiąkalski, S. Waltoś, A. Zoll, Kraków 1994, s. 148; S. Mir Puig, Die begründende und begrenzende Funktion der positiven Generalprävention”, ,Zeitschrift für die gesamte Strafrechtswissenschaft" 1990, nr 102, wyd. 4, s. 918-919 oraz lit. tam podana.

30 B. Szamota-Saeki, Pozytywna prewencja ogólna $w$ nauce niemieckiej, ,Archiwum Kryminologii” 2003-2004, T. XXVII, s. 51.

31 R. Kaczor, Rola sqdu i prokuratora przy wymiarze kary, „Prokuratura i Prawo” 2009, nr 11-12, s. 20-21. 
Zgodnie z intencją twórców kodeksu karnego za podstawowe kryterium przy wymierzaniu kary uwzględniającej dyrektywę pozytywnej prewencji ogólnej należałoby uznać: potrzebę odwołania się przez sąd do poglądów opinii społecznej na temat wymierzanej reakcji penalnej oraz dokonanie na tej podstawie ustalania - czy dana kara: ,jeszcze satysfakcjonuje czy już nie satysfakcjonuje" 32 wspomnianą opinię publiczną. Wskazany kierunek interpretacji wzbudza jednakże pewne zastrzeżenia. Wydaje się bowiem, że pominięto w nim nie tylko istotę oddziaływania ogólnoprewencyjnego (którą pozostaje zapobieganie przestępczości) ${ }^{33}$, lecz także nie dostrzeżono trudności badawczych, związanych z metodą „ustalania” poglądów „bezimiennej” opinii publicznej oraz z wątpliwą kwestią uwzględnienia wyrażonej przez społeczeństwo opinii przez organy wymiaru sprawiedliwości. Zaprezentowane ujęcie prowadziłoby $\mathrm{w}$ istocie do paradoksalnych wniosków, gdyż w świetle jego założeń: „trudno byłoby mówić o kształtowaniu świadomości prawnej kogokolwiek, tu właśnie [...] świadomość prawna [...] członków społeczeństwa kształtowałaby karę" 34 . Dostrzeżone tutaj wątpliwości sugerują w rezultacie, że odwoływanie się tylko do poglądów „opinii publicznej” przesuwa analizowaną problematykę w sferę ,mglistych ocen”, na podstawie których nie sposób uzyskać rzetelnych informacji pozwalających na określenie ,potrzeb w zakresie kształtowania świadomości prawnej społeczeństwa"35.

Nie bez racji podnosi się zatem w judykaturze, że: „Racjonalny wymiar kary, wsparty rzetelną analizą materiału procesowego, oparty także na zasadach doświadczenia życiowego Sądu, nie wymaga odwoływania się do społecznego poczucia sprawiedliwości, zwłaszcza że u różnych przedstawicieli społeczeństwa może być ono rozmaicie rozumiane"36.

32 K. Buchała, Glos w dyskusji, [w:] Problemy reformy prawa karnego, red. T. Bojarski, E. Skrętowicz, Lublin 1993, s. 340.

${ }^{33}$ K. Buchała, A. Zoll, Polskie prawo karne, Warszawa 1997, s. 13.

34 K. Skowroński, op. cit., s. 84; T. Kaczmarek, Sędziowski wymiar kary w Polskiej Rzeczypospolitej Ludowej w świetle badań ankietowych, Wrocław 1972, s. 288-290.

35 T. Kaczmarek, O pozytywnej prewencji w ujęciu projektu kodeksu karnego z 1994 r., „Palestra” 1995, nr 3-4, s. 71; idem, Sędziowski wymiar kary..., s. 75; M. Szerer, op. cit., s. 172.

36 Wyrok Sądu Apelacyjnego w Katowicach z dnia 20 marca 2008 r., II AKa 61/08, LEX nr 410425. 
W konsekwencji wypadałoby zatem podkreślić, że wspomniane poczucie jest kategorią socjologiczną, zmienną, zależącą od wielu czynników, nierzadko subiektywnych, wynikających z odczuwanych emocji czy stopnia nagłośnienia danej sprawy karnej. Społeczne oceny mogą zaś rozmijać się z ustaleniami poczynionymi przez sąd, jak również z oceną pewnych faktów, którymi opinia publiczna nie jest zainteresowana ${ }^{37}$. Stąd też w judykaturze podnosi się, że:

Dla wymiaru kary nie ma żadnego znaczenia »społeczne poczucie sprawiedliwości«. Jak to i dawniej formułowano, pojęcie to wyraża raczej własne wyobrażenia osób nim się posługujących, tak bardzo jest owo poczucie nieprecyzyjne i niezbadane, bo nikt nie zbadał jak społeczeństwo ocenia sądzone przestępstwa. Nie ma też powodu, by niezawisły sąd podporządkowywał swój wyrok nastrojom jakiejś grupy ludności, z natury rzeczy nieprawidłowymi, bo opartymi zwykle o niepełną znajomość realiów zdarzenia, wyrażanymi bez poczucia odpowiedzialności za losy osób w nim uwikłanych. Po to obdarzono sędziów niezawisłością, by orzekali sprawiedliwie, a nie po to, by spełniali doraźnie powstające, czasem umyślnie kreowane nastroje jakichś grup mieszkańców, nie zawsze zgodne, rzadko stabilne, zwykle nieracjonalne. Nie byłyby sprawiedliwe wyroki oparte na domniemywaniu takich nastrojów ${ }^{38}$.

W świetle powyższych ustaleń można by zatem stwierdzić, że bezrefleksyjne odwoływanie się przy wyrokowaniu do „społecznego poczucia sprawiedliwości” wprowadza do procesu wyrokowania „element sztuczny" czy też, inaczej mówiąc, kryterium, którego nie sposób bliżej określić ani zmierzyć. Przewidywany w tym zakresie pluralizm opinii społecznej, jak również niejednolitość, zmienność oraz podatność tych poglądów na socjotechniczne manipulacje w tym zakresie utwierdzają w przekonaniu, jak doniosłą rolę w tym zakresie odgrywa zasada sędziowskiej niezawisłości ${ }^{39}$.

Niezależnie od ogólnej aprobaty zaprezentowanych stanowisk, należałoby jednak zastanowić się, czy sąd orzekający powinien pozo-

\section{Ibidem.}

38 Wyrok Sądu Apelacyjnego w Krakowie z dnia 28 grudnia 2007 r., II AKa 223/07, „Krakowskie Zeszyty Sądowe” 2008, nr 3, poz. 27.

39 Wyrok Sądu Apelacyjnego w Krakowie z dnia 3 lipca 2002 r., II AKa 3/02, „Krakowskie Zeszyty Sądowe" 2000, nr 7-8, poz. 39; Wyrok Sądu Apelacyjnego w Krakowie z dnia 16 grudnia 2003 r. II AKa 333/03, „Krakowskie Zeszyty Sądowe” 2004, nr 2, poz. 19 . 
stawać obojętny wobec społecznie aprobowanych wartości, a tym samym względem poglądów opinii publicznej na temat karania sprawców przestępstw ${ }^{40}$ ? Z jednej bowiem strony wypadałoby stwierdzić, że sądy nie mogą ulegać społecznej presji, jak również kierować się tymi jej odczuciami, które są, zwłaszcza z punktu widzenia współczesnej wiedzy o racjonalnym prawie, wręcz anachroniczne. Ich zadaniem nie jest bowiem uleganie opinii publicznej, ale dążenie - poprzez stosowane prawo — do jej kształtowania w pożądanym kierunku. Z drugiej jednak strony, przy wielu zastrzeżeniach, pojawia się również pytanie, czy nieznajdująca „sojusznika” w opinii publicznej kara kryminalna może w istocie spełnić swoje zadania w zakresie kształtowania świadomości prawnej społeczeństwa, jak również oddziaływać na pronormatywne postawy obywateli ${ }^{41}$ ?

Poszukując dalej sui generis czynników, które uzasadniałyby odwołanie się do treści dyrektywy ogólnoprewencyjnej, wydaje się, że również kryterium nagminności popełniania przestępstw nie pozostaje w tym zakresie odpowiednim miernikiem ${ }^{42}$. W judykaturze podkreśla się wprawdzie, że jednym z celów, który ma osiagnnąć kara — wskazanym w art. 53 $\S 1$ k.k. - jest zapobieganie popełnianiu przestępstw, zwłaszcza tych nagminnych ${ }^{43}$, to jednak nie sposób pominąć, że powoływanie tej okoliczności może wzbudzać negatywne asocjacje do okresu obowiązywania kodeksu karnego z 1969 r. ${ }^{44}$, w którym służyła ona jako uzasadnienie dla

${ }^{40} \mathrm{~W}$ orzecznictwie zwrócono bowiem uwagę, że postulat nieulegania nastrojom społecznym: „Nie oznacza [...], że Sąd, wydając orzeczenie, ma być obojętny na normy obyczajowe, czy też zasady współżycia społecznego, jeśli jednak opiera na nich swoje rozstrzygnięcie, powinien je wskazać w motywach pisemnych orzeczenia i uzasadnić odwołanie się do nich". Wyrok Sądu Apelacyjnego w Katowicach z dnia 20 marca 2008 r., II AKa 61/08, LEX nr 410425.

${ }^{41}$ S. Zabłocki, Glosa do wyroku Sadu Najwyższego z dnia 22 III 1974, IV KRN 6/74, „Państwo i Prawo” 1975, nr 10, s. 180-181.

42 Należy podkreślić, że w świetle obowiązującej regulacji karnej przesłanka „nagminności", motywowana względami ogólnoprewencyjnymi, nie może uzasadniać wymierzenia sprawcy kary powyżej stopnia jego winy. W przeciwnym bowiem wypadku oznaczałoby to instrumentalne traktowanie sprawcy (zatem sprzeczne także m.in. z art. 3 k.k.).

43 Postanowienie Sądu Najwyższego z dnia 28 listopada 2008 r., V KK 161/08, LEX nr 477911.

44 Ustawa Kodeks karny z dnia 19 kwietnia 1969 r., Dz.U. Nr 13, poz. 94 ze zm. 
wymierzania surowych, odstraszających $\mathrm{kar}^{45}$. Ponadto, należy również podkreślić, że sama wykładnia tego pojęcia nasuwa w istocie szereg wątpliwości interpretacyjnych. Nie bez racji podnosi się, iż wspomniana:

Nagminność określonego rodzaju czynów pozostaje tak długo kwestią abstrakcyjną, jak długo nie zostanie udowodniona. Sąd winien więc wykazać dlaczego i co przemawiało za tym, że na terenie jurysdykcji sądu orzekającego [...] określone przestępstwa są nagminne. Ile tego rodzaju spraw zawisło przed tym konkretnym, rzeczowo właściwym do rozpoznania danej sprawy sądem, a ile tego rodzaju spraw rozpoznawanych jest na terenie właściwości innych sądów. Jak owa liczba spraw ma się do liczby ludności zamieszkującej teren właściwości danego sądu $[\ldots]^{46}$.

Z powyższych uwag wynika zatem, że kryterium nagminności wymaga nie tylko rzetelnej oceny, lecz także — przy jego ewentualnym eksponowaniu w procesie sądowego wymiaru kary — przestrzegania współczesnych standardów ${ }^{47} \mathrm{w}$ zakresie prowadzenia racjonalnej polityki karnej ${ }^{48}$.

Od wielu zastrzeżeń nie pozostawała również wolna kolejna propozycja interpretacyjna, w której przekonywano, że okoliczności wpływające na stopień społecznego niebezpieczeństwa (obecnie stopień społecznej szkodliwości) czynu okazywałyby się miarodajne dla oceny wymiaru kary z punktu widzenia dyrektywy ogólnoprewencyjnej ${ }^{49}$. Próba utożsamienia kryteriów oceny społecznego niebezpieczeństwa czynu z kryte-

45 Takie ujęcie nagminności byłoby zatem sprzeczne ze współcześnie zaaprobowaną aksjologią karania.

46 Wyrok Sądu Apelacyjnego w Łodzi z dnia 20 lutego 2014 r., II AKa 9/14, LEX nr 1444756; Wyrok Sądu Apelacyjnego w Lublinie z dnia 16 lutego 2010 r., II AKa 7/10, LEX nr 658787.

47 Wyrok Sądu Apelacyjnego w Krakowie z dnia 23 listopada 2000 r., II AKa 147/00, „Krakowskie Zeszyty Sądowe” 2001, nr 1, poz. 24.

48 W judykaturze wyrażono m.in. pogląd, że: „Nagminność przestępczości tymczasem jest okolicznością skutkującą potrzebą wymierzenia kary surowszej, ale tylko przewyższającej dolny próg ustawowego zagrożenia". Wyrok Sądu Apelacyjnego w Łodzi z dnia 4 lipca 2001 r., II AKa 106/01, „Krakowskie Zeszyty Sądowe” 2002, nr 5, poz. 58.

${ }^{49} \mathrm{~K}$. Buchała, Ogólne dyrektywy sqdowego wymiaru kary w projekcie kodeksu karnego, „Państwo i Prawo” 1969, nr 2, s. 312; A. Zoll, Stopień spolecznego niebezpieczeństwa czynu jako dyrektywa wymiaru kary, „Nowe Prawo” 1969, nr 6, s. 940; K. Buchała, Społeczne niebezpieczeństwo czynu jako dyrektywa sqdowego wymiaru kary, „Krakowskie Zeszyty Prawnicze" 1970, nr 3, s. 145; Uzasadnienie do projektu rzqdowego zmiany k.p.k. Reforma procedury karnej, „Demokratyczny Przegląd Prawniczy” 1949, nr 6-7, s. 10.

Nowa Kodyfikacja Prawa Karnego 39, 2016

(C) for this edition by CNS 
riami decydującymi o treści przesłania ogólnoprewencyjnego nie wydaje się jednak trafna. Przykładowo, na podstawie jednego z kwantyfikatorów społecznej szkodliwości czynu w postaci „rozmiaru wyrządzonej przez sprawcę szkody", trudno byłoby w istocie uzyskać jakąkolwiek wartość prognostyczną dotyczącą określonego środowiska społecznego ${ }^{50}$.

\section{Uwagi końcowe}

Zasygnalizowane powyżej kontrowersje interpretacyjne prowadzą do wniosku, że odwoływanie się przez sąd do treści dyrektywy ogólnoprewencyjnej nie pozwala na uzyskanie konkretnej wartości prognostycznej dla wymierzanej kary ${ }^{51}$. Sugestia o - w istocie - dekoracyjnym charakterze wspomnianej dyrektywy skłaniała tym samym do konstatacji, że odzwierciedla ona w istocie ,piękne hasła”, które wprawdzie „ładnie brzmią”, ale ich ogólnikowość i daleko idąca niekonkretność nie pozwalają na uzyskanie potrzebnych wartości wskaźnikowych dla sądowego wymiaru kary ${ }^{52}$. Stąd też w literaturze przedmiotu podniesiono, że kodeksowe, ogólnoprewencyjne przesłanie nie odzwierciedla w rezultacie: ,[...] jakiejkolwiek dyrektywy sądowego wymiaru kary. Ujęcie takie - jak argumentowano dalej — nie daje sądowi żadnej wskazówki, na podstawie której mógłby on wyrobić sobie chociażby bardzo ogólny pogląd - jaka co do rodzaju i wysokości kara mogłaby dopiero stabilizować normy, a która tej właściwości stabilizującej byłaby już pozbawiona"53. Powyższe stanowisko przekonywało więc, że sens dyrektywy prewencji ogólnej okazuje się nie tylko enigmatyczny, ale również interpretacyjnie skomplikowany przy próbie przełożenia go na język praktyki ${ }^{54}$. Negatywna ocena odwoływania się przez ustawodawcę do stricte heurystycznych metod wynikała bowiem z przeświadcze-

50 J. Giezek, Okoliczności wptywające na sędziowski wymiar kary, Wrocław 1989, s. $167-168$.

51 L. Gardocki, Prawo karne, Warszawa 1999, s. 177.

52 W. Mącior, W sprawie reformy prawa karnego, „Państwo i Prawo” 1991, nr 10, S. 94.

53 T. Kaczmarek, O pozytywnej prewencji ogólnej..., s. 69.

54 T. Bojarski, Uwagi o dalszych projektowanych zmianach części ogólnej kodeksu karnego, [w:] Nowe prawo karne po zmianach, red. T. Bojarski, E. Skrętowicz, Lublin 2002, s. 62.

Nowa Kodyfikacja Prawa Karnego 39, 2016

(C) for this edition by $\mathrm{CNS}$ 
nia, że samo dążenie do utwierdzenia w społeczeństwie przekonania, że: „[...] W walce z przestępczością zwycięża praworządność, że przestępcy są sprawiedliwie karani" 55 , nie oznacza, aby myśl o tej „propagandzie” przyświecała sędziemu w chwili, w której przykładowo zastanawiałby się, czy sprawcy powinien wymierzyć trzy, czy też może cztery lata pozbawienia wolności. W konsekwencji wypada więc zauważyć, że próba ustalenia ${ }^{56}$ niezbędnego bądź przynajmniej wystarczającego „kwantum” dla osiagnięcia stabilnego obowiązywania norm okazuje się niewątpliwie bardzo trudna do przeprowadzenia ${ }^{57}$.

W wyrażonych obawach co do dyrektywalnego statusu prewencji ogólnej utwierdzają także wyniki badań empirycznych ${ }^{58}$, które nie pozwalają na precyzyjnie określenie, czy, a jeśli tak, to jaką rolę o charakterze przeciwprzestępczym odgrywają dla świadomości społecznej instrumenty pozostające $\mathrm{w}$ tradycyjnie postrzeganym arsenale pozytywnej prewencji ogólnej ${ }^{59}$. Oznaczało to w rezultacie, że pozytywna prewencja ogólna nie różni się pod tym względem od swojej negatywnej poprzedniczki, która również nie przyczyniła się do sformułowania jednoznacznej odpowiedzi na temat mechanizmów powstrzymujących

55 M. Szerer, Problematyka społecznego oddziaływania kary, „Państwo i Prawo” 1974, nr 5, s. 18.

56 H.H. Jescheck, Strafgesetzbuch. Einführung, München 1987, s. XII.

${ }^{57}$ H.H. Jescheck, T. Weigend, Lehrbuch des Strafrechts. Allgemeiner Teil, Berlin 1996, s. 881.

58 Jak wskazano w piśmiennictwie, w ujęciu doświadczalnym prewencja ogólna pozostaje procesem niepoddającym się prostej, bezpośredniej obserwacji. B. Szamota, Badania nad prewencja generalnq: problemy metodologiczne, ,Archiwum Kryminologii" 1984, T. XI, s. 100. Trafnie autorka oceniła, że nie można przecież ad hoc zaobserwować kogoś: ,[...] kto powstrzymuje się od popełnienia przestępstwa ze strachu przed karą" czy też — uzupełniając - z szacunku do przestrzegania prawa.

59 F. Schumann, Positive Generalprävention. Ergebnisse und Chancen der Forschung, Heidelberg 1989, s. 20-25; B Szamota, Prewencja ogólna w świetle badań empirycznych, „Państwo i Prawo” 1986, nr 5, s. 54; W. Minor, Deterrence Research: Problems of Theory and Method, [w:] Preventing Crime, red. J.A. Cramer, Beverly Hills 1978, s. 35; B. Szamota-Saeki, Wplyw prawa karnego na przekonania moralne społeczeństwa w świetle wybranych badań empirycznych, „Archiwum Kryminologii” 2007-2008, t. XXIX-XXX, s. 203-213; K. Hart-Hönig, Gerechte und zweckmäßige Strafzumessung. Zugleich ein Beitrag zur Theorie positiver Generalprävention, Berlin 1992, s. 47-48; A. Linden, M. Similä, General Deterrence and the General Sense of Justice, [w:] The National Council for Crime Prevention. General Deterrence, Sztokholm 1975, s. 181. 
społeczeństwo przed popełnianiem przestępstw ${ }^{60}$. Wobec powyższego trafny pozostaje pogląd W. Woltera, w którym autor już w okresie międzywojennym przekonywał, że dokładne zbadanie efektów oddziaływania prewencji ogólnej: „wymagałoby tak ryzykownego eksperymentu, jak zniesienie sankcji karnych. Dopiero, gdyby wtedy ilość przestępstw nie wzrosła, kwestię prewencji ogólnej można by uważać za definitywnie załatwioną"61.

Przeprowadzone rozważania skłaniają więc do zastanowienia się nad tym, czy sądowe odwoływanie się do celów ogólnoprewencyjnych, których treści nie sposób przełożyć na język praktyki, nie pozostaje $\mathrm{w}$ istocie prostym, często bezrefleksyjnym recypowaniem sformułowań ustawowych, „ukutych frazesów”, które - jak oceniał M. Szerer — są jedynie: „refrenem, który spływa spod pióra bez żadnego wysiłku myślowego autora uzasadnienia i [...] osłonięciem faktu, że kara była wymie-

${ }^{60}$ D. Sutherland, Murder and the Death Penalty, ,Journal of the American Institute of Criminal Law and Criminology" 1925, vol. 15, s. 522; T. Sellin, Capital Punishment, New York 1967; H. Bedau, Deterrence and the Death Penalty: A Reconsideration, "Journal of Criminal Law, Criminology and Political Science" 1970, vol. 61, s. 539; B. Szamota, Badania nad..., s. 94. Warto w tym miejscu podkreślić, że jeszcze innym typem badań było porównywanie współczynników morderstw w ramach tego samego ustawodawstwa przed i po egzekucjach. Odmienne wyniki nad skutecznością odstraszającego oddziaływania kary śmierci odnotował natomiast W.F. Graves, The Deterrent Effect of Capital Punishment in California, [w:] The Death Penalty in America, red. H.A. Bedau, New York 1964, s. 322-332. Należy jednak podkreślić, że również współcześnie przeprowadzone badania nie potwierdziły jednoznacznie odstraszającego oddziaływania kary śmierci. Zob. I. Ehrlich, The Deterrent Effect of Capital Punishment: A Question of Life and Death, „American Economic Review” 1975, vol. 65, s. 397; R. Cooter, T. Ulen, Ekonomiczna analiza prawa, red. przekładu J. Bełdowski, K. Metelska-Szaniowska, Warszawa 2009, s. 637-638; B. Szamota, Prewencja ogólna w świetle..., s. 47; H. Dezhbakhsh, J. Shepherd, Odstraszajacy wpływ kary śmierci. Dowody na podstawie eksperymentu sqdowego, [w:] Bezpieczne państwo. Nowe trendy w polityce karnej, red. J. Czabański, Kraków 2005, s. 93 n.; J. Czabański, Czy kara działa?, [w:] Bezpieczne państwo. Nowe trendy w polityce karnej, red. J. Czabański, Kraków 2005, s. 15 n; J.J. Donohue, J. Wolfers, Uses and Abuses of Empirical Evidence in the Death Penalty Debate, „Stanford Law Review” 2005, vol. 58, s. 791-846.

61 W. Wolter, Zarys systemu prawa karnego, T. 2, Kraków 1934, s. 17. Zob. także E. Durkheim, Zasady metody socjologicznej, przeł. J. Szacki Warszawa 1968, s. 100; R. Witt, A. Dryden Witte, Odstraszanie i izolacja, przeł. J. Czabański, „Ius et Lex” 2007, nr 1, s. 139. 
rzona „na wyczucie sędziowskie" ${ }^{62}$ ? Wysunięte powyżej zastrzeżenia mogą bowiem sugerować, że komentowana dyrektywa ogólnoprewencyjna pozostaje w istocie ,zbitką słów”, która treściowo nie dotrzymuje jednak tego, co obiecuje ${ }^{63}$.

Na podstawie przedstawionych rozważań można by postulować pominięcie dyrektywy prewencji ogólnej z regulacji art. 53 § 1 k.k. Wydaje się bowiem, że sens oddziaływania ogólnoprewencyjnego znajduje już swoje wystarczające odzwierciedlenie w ramach ustawowego zagrożenia karą. Stąd też wypadałoby dopowiedzieć, że realizację kodeksowych „potrzeb w zakresie kształtowania świadomości prawnej społeczeństwa” na etapie jurysdykcyjnym zapewnia sam moment wyrokowania, który de facto potwierdza kodeksową zapowiedź określonej reakcji penalnej ${ }^{64}$. W konkluzji należałoby więc stwierdzić, że nawet całkowite pominięcie założeń ogólnoprewencyjnych — expressis verbis — w obowiązującej kodyfikacji nie przekreślałoby ich obecności w procesie racjonalnego wymiaru kary.

\section{Positive general prevention directive - selected problems. Comments in the context of the Penal Code}

\section{Summary}

This article presents basic reservations concerning the prescriptive status of general prevention. Concerns reported in this respect are related not only to its formulation in the act, but also to its substantive meaning. In the light of the findings, it is concluded that the sense of general preventive effect is already sufficiently reflected in the statutory penalty. Therefore, it would be right to add that the "needs to develop legal awareness in society" (Art. $53 \S 1$ of Penal Code) referred to in the Code at the jurisdictional stage are satisfied by the very moment of passing a sentence, which de facto confirms a certain

${ }^{62}$ M. Szerer, Karanie a..., s. 144.

${ }^{63}$ M. Szerer, Problematyka społecznego ..., s. 29. Warto w tym miejscu podkreślić, że już w latach osiemdziesiątych pojawiły się postulaty domagające się wyeliminowania dyrektywy ogólnoprewencyjnej z przepisów kodeksu karnego z 1969 r. Zob. J. Jakubowska-Hara, Podstawowe dyrektywy wymiaru kary (w świetle dyskusji wokót art. 50 k.k.), „Ruch Prawniczy, Ekonomiczny i Socjologiczny” 1989, nr 4, s. 99 n.; także W. Mącior, Ogólne dyrektywy sq̨dowego wymiaru kary, „Państwo i Prawo” 1982, nr 11, s. 119-129.

${ }^{64}$ T. Kaczmarek, Problem indywidualizacji wymiaru kary sprawiedliwej i celowej, [w:] Dyrektywy sqdowego wymiaru kary, red. J. Majewski, Warszawa 2014, s. 20. 
penal reaction provided for in the Code. Therefore, it should be concluded that even the total omission of the general prevention assumptions - expressis verbis - in the current codification would not exclude their presence in the process of rational sentencing.

Keywords: judicial sentencing, the general prevention directive, forming the legal awareness of the society. 